\title{
Da Frustração ao Enfrentamento do Cuidado para a Morte por Técnicos de Enfermagem
}

\author{
Almeida, Débora Vieira de; Silvia, Lívia Maria Beraldo; Bocchi, Cristina Mangini \\ Unesp - Botucatu — deboravalmeida@gmail.com
}

Introdução: o desenvolvimento das ciências médicas possibilitou a cura de diversas doenças e o prolongamento da vida, gerando a questão: até quando prolongar a vida de uma pessoa preservando a sua dignidade? Isso traz à discussão a eutanásia, a distanásia e a ortotanásia. o Conselho Federal de Medicina (Brasil) publicou resoluções com a intenção de regulamentar a ortotanásia (Resolução n. 1.805/06) e de proporcionar a autonomia do paciente sobre o seu processo de morte (Resolução n. 1.995/12). Considerando que no exercício da enfermagem nas UTIs brasileiras os técnicos são os que mais contribuem para a execução do planejamento da assistência, sob responsabilidade do enfermeiro, a escassez de pesquisas explorando a vivência de técnicos de enfermagem sobre o cuidado para a morte de pacientes no final da vida e por se tratar de objeto polêmico no campo da Bioética; os objetivos: compreender a experiência de técnicos de enfermagem sobre o cuidado para a morte de pacientes terminais na Unidade de Terapia Intensiva (UTI) e configurar um modelo teórico que a represente. Método: Pesquisa qualitativa, realizada com técnicos de enfermagem de uma UTI de um Hospital Escola do interior paulista, após esclarecimento, consentimento e assinatura do Termo de Consentimento Livre e Esclarecido. a saturação teórica deu-se mediante análise da 10a entrevista não diretiva, segundo a Teoria Fundamentada nos Dados. Utilizou-se como referencial teórico o Interacionismo Simbólico. Projeto desta pesquisa foi aprovado pelo Comitê de Ética em Pesquisa local. Resultados: Categoria central: da frustração ao enfrentamento do cuidado digno de enfermagem para a finitude: a aceitação da morte como componente terapêutico e interveniente. Esta emergiu da comparação dos subprocessos: não se sentindo preparado para o cuidado para a morte, aceitando a morte como um fenômeno terapêutico, desenvolvendo estratégias de enfrentamento. Segundo o Interacionismo Simbólico, a frustração do profissional iniciante em cuidar da pessoa para a morte está relacionada à sua interação e interpretação da situação, por sentir-se preparado somente para assistir à pessoa para a vida. Conclusão: Estudo revelou a dificuldade de enfrentar a morte no início da profissão; a criação de estratégias de enfrentamento individual; aceitação da morte como um fenômeno terapêutico; defesa da manutenção dos cuidados mínimos e a aceitação da ortotanásia, a qual atenta para o fato de respeitar o bem estar do individuo garantindo sua dignidade, não antecipando a morte e nem postergando-a, pois é um processo natural da vida.

Almeida, Débora Vieira de; Silvia, Lívia Maria Beraldo; Bocchi, Cristina Mangini. Da Frustração ao Enfrentamento do Cuidado para a Morte por Técnicos de Enfermagem. In: Anais do Congresso Internacional de Humanidades \& Humanização em Saúde [= Blucher Medical Proceedings, num.2, vol.1]. São Paulo: Editora Blucher, 2014. ISSN 2357-7282

DOI 10.5151/medpro-cihhs-10589 